\title{
EXPERIMENTAL DETERMINATION OF THE MECHANICAL PROPERTIES OF COMPOSITE MATERIALS PRODUCED WITH PARTICLE REINFORCED ADHESIVES
}

\author{
Hamit ADIN ${ }^{1}$, Burhan SEVEN ${ }^{2}$, Fahri ÇAKAR ${ }^{3}$, Hayri YILDIRIM ${ }^{4}$, Isa ATAŞ ${ }^{5}$ \\ ${ }^{1}$ Mechanical Engineering Departmant / Batman University, Turkey \\ ${ }^{2}$ Diyarbakır Technical Science Vocational School / DicleUniversity, Turkey \\ ${ }^{3}$ Diyarbakır Technical Science Vocational School / DicleUniversity, Turkey \\ ${ }^{4}$ Diyarbakır Technical Science Vocational School / DicleUniversity, Turkey \\ ${ }^{5}$ Diyarbakır Technical Science Vocational School / DicleUniversity, Turkey \\ *Corresponding author; E-mail: hamit.adin@batman.edu.tr
}

\begin{abstract}
The composite adhesives which are produced by adding particles into the structural adhesives used in aviation field as well as the latest developments in nanotechnology have given a new perspective to the design of adhesively bonded joints. In this study, the mechanical aspects of fibre glass composite materials produced with method hand lay-up by adding powder of composite material into adhesives were examined with an experimental manner under tensile load. Polyester was used as the structural adhesives; powder of fibre glass composite materials was used as additive materials at $1 \%$ or $2 \%$ by weight, and the samples of tensile were produced. The results of the experiment showed that tensile failure load was increased in the fibre glass composite material bonded with particle-reinforced adhesive. In addition, the study examined the force-displacement curves and found that the joints with nanoparticle-added adhesive had an increased displacement capacity.
\end{abstract}

Key words: Particule, Polyester, Composite material, Tensile test, Mechanical properties

\section{INTRODUCTION}

The physical life is important for the machines and equipment that are recommended to meet human needs. It is also important to provide this material as much as the mechanism of the machine. This material has led to the existence of different approaches. The emergence of composite materials is also a result of this approach [1]. For this reason, the rapid development and increasing competition in the aerospace, automotive, aerospace and defence industries have necessitated the design of products with high performance. To respond this need, composite materials have been started to be produced since 1950, and the usage area has became increasingly widespread day by day [2]. In today's competitive environment, better quality products have to be supplied to the market at lower costs. This need necessitates the development and use of new generation materials in the industry. Lighter, more rigid and higher-strength materials are needed 
in many engineering applications in the industry [3]. As a result of the progress of the technology with an increasing momentum, the performance of the existing materials can be inadequate for the increasing working conditions today [4]. The most important feature of composite materials is to select the composite materials constituting the composite material according to the application and combine them on the ideal side. Composite materials have been taken from nature, and have been used for a very long time through history. The mudbrick used in the rural areas of our country is the most primitive example of composite materials. The mudbrick has a structure reinforced with straw. A varied materials such as metals, light metals, ceramics and plastics are used as matrix in the production of composite materials. Glass, carbon, plastic, metal or light metal fibres are the most commonly used as reinforcement elements [5]. The most widely used composites today are glass fibre-polyester, tungsten, molybdenum-reinforced aluminum, carbon and steel fibre reinforced plastics. Production methods such as hand lay-up, spraying, fibre winding, vacuuming, extrusion, injection and pultrusion of composite materials are available [6]. Although the manual depositing method requires extensive workmanship and the manufacturing capacity is low, it is the most widely used and economical metot for non-serial production. The reinforced fabrics made from woven or chopped fibres are deposited on the prepared mold by hand, and then the liquid resin is absorbed into the fibre layers. Before the fibre is laid, the molds are cleaned and polyester resin is applied. After the polyester resin is hardened, the fibre layers are laid one by one. The reinforcement element and polyester application are continued in the same manner until the material reaches the desired thickness. In this process, it is important that the resin penetrates well into the fibre fabric. Polyester, vinyl-ester and phenolic resins are the most preferred reinforcement elements placed by hand lay-up technique [7]. The mechanical properties of composite materials vary depending on many factors. Among them, the reinforcement volume ratio and reinforcement particle size are quite effective. It has been reported that some mechanical properties such as tensile strength have been increasing steadily as the reinforcement volume ratio increases $(8,9)$, in studies conducted by Ganesh and Chawla, 2005; Min, 2009. In some studies, (Slipenyuk, Kuprin, Milman, Spowart and Miracle, 2004; Liu, Wang, Xiao, Ma and Liu, 2010) these properties have been found to fall after a certain reinforcement volume value $[10,11]$. In terms of the effect on the mechanical properties of the reinforcement particle size, improvement of the mechanical properties has been observed as the reinforcement particle size has decreased [12,13,14,15]. O'Donnell and Looney (2001) suggested that large reinforcement particles are more advantageous at certain reinforcement volume ratios in a study they conducted [16]. The effects of matrix powder size on mechanical properties have not yet been investigated in the literature. However, the ratio of the matrix powder size to the reinforcement particle size influences the material mechanical properties by influencing the distribution of the reinforcement particles in the microstructure. In addition, the reinforcement volume ratio can determine the effect of the matrix powder / reinforcement particle size ratio on the mechanical properties. Meguid et al [17] investigated the effect of nanoparticle reinforcement on the static strength of the connections by making carbon nanotubes and aluminium nanopowder reinforcements in different proportions in the epoxy adhesive. Experiments have shown that the ratio of nanoparticles incorporated in the adhesive is a very important parameter in the tensile and shear strengths of the connections. Srivastava [18] carried out tensile tests by making 3\% multi- 
walled carbon nanotube reinforcement into epoxy adhesive. As a result, the static strength of the connections using nanoparticle reinforced epoxy adhesive was found to be higher than those of non-nanoparticle reinforced connections. They investigated the effect of $\mathrm{SiC}$ and $\mathrm{Al}_{2} \mathrm{O}_{3}$ nanoparticles on the tensile strength of the bond they bound at certain ratios in the epoxy adhesive. Experiments have shown that the relation of the nanoparticle reinforcement into the epoxy adhesive significantly increases the maximum tensile strength.

Nowadays, in the workshops of composite material production, dust is coming onto the stage when cutting the composite plates in order to bring the composite plates to desired sizes. These powders have both economic and environmental impacts. These powders can be evaluated in various branches of the industry. In this presented work, glass fibre composite material was produced by hand lay-up method. To see the effect of glass fibre powder on the mechanical properties of composite materials, glass fibre reinforced composite material was produced by joining the particle size glass fibre slurry to the structural adhesive. The produced composite layers were cut to obtain tensile specimens and the damage loads under tensile load were experimentally determined. In addition, glass fibre dust was compared with the experimental damage loads of composite materials that have not been added to the glass fibre dust with damage loads of the composite materials joined.

\section{MATERIALS AND METHODS}

Glass fibre composite powders and fibres used in the production of composite materials were supplied from İzoreel, located in İzmir, for use in experimental works. The samples were produced as shown in Figure 1 and cut into dimensions of 250x250 mm x mm. Glass fibre composites were manufactured by hand lay-up method. Glass fibre powders were mixed into polyester adhesive used in the production of composite materials. In order to distribute the glass fibre powders homogeneously in the polyester, mixing was performed with a three-axis mixer for 1 hour and particle reinforced fibre composites were produced. The composite material, both particle-reinforced and non-particle-reinforced, was fabricated as shown in Figure 1 with four layers. Particle-free composite materials and particle-added composite materials were produced at the same rates / quantities and by hand-laying method. Accelerator was used in the production of composite materials, but no hardener was used. Produced layer was subjected to pressing process. The composite layers were allowed 48 hours to solidify. Sintering was applied to achieve full integration and maximum density of the particles between the powder and the particles. For this purpose, the composite layer was dwelled for 3 hours to remove and sinter the oven samples adjusted to $400^{\circ} \mathrm{C}$.

\subsection{Tensile Tests}

Tensile tests are mechanical tests that are used to determine the mechanical properties of materials under static load and to classify the materials according to their properties. These tests involve the withdrawal of test specimens prepared in accordance with the standards to determine the mechanical properties of the materials, usually to the point of detachment. After the production of the layer, 5 test pieces were taken from the plates produced by each production 
method and the total of 10 test samples were obtained by cutting with water jet. Samples for particulate and non-particulate composite materials were produced in accordance with ASTM standards for the tensile test at the scale shown in Figure 2. The specimens were manufactured to have a width of $20 \mathrm{~mm}$, a length of $250 \mathrm{~mm}$ and a thickness of $2 \mathrm{~mm}$. Tensile tests; They were conducted using a video extensometer in a $5 \mathrm{kN}$ Shimadzu universal drawing device. In the pull tests, the experiment continued until all the specimens reached the breaking point by the movement.
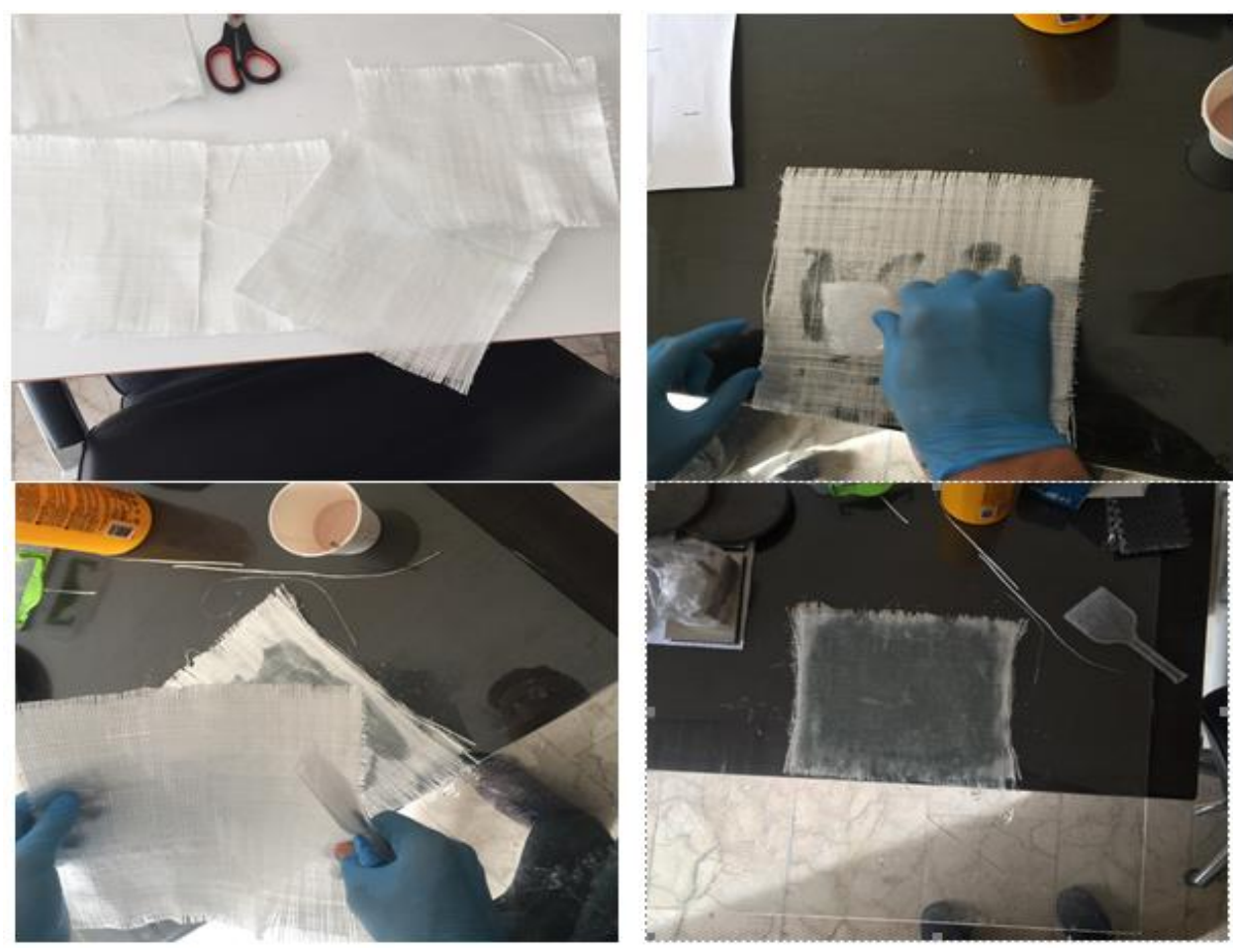

Figure 1. Production of Glass Fibre Reinforced Composite Material by Hand lay-up Method
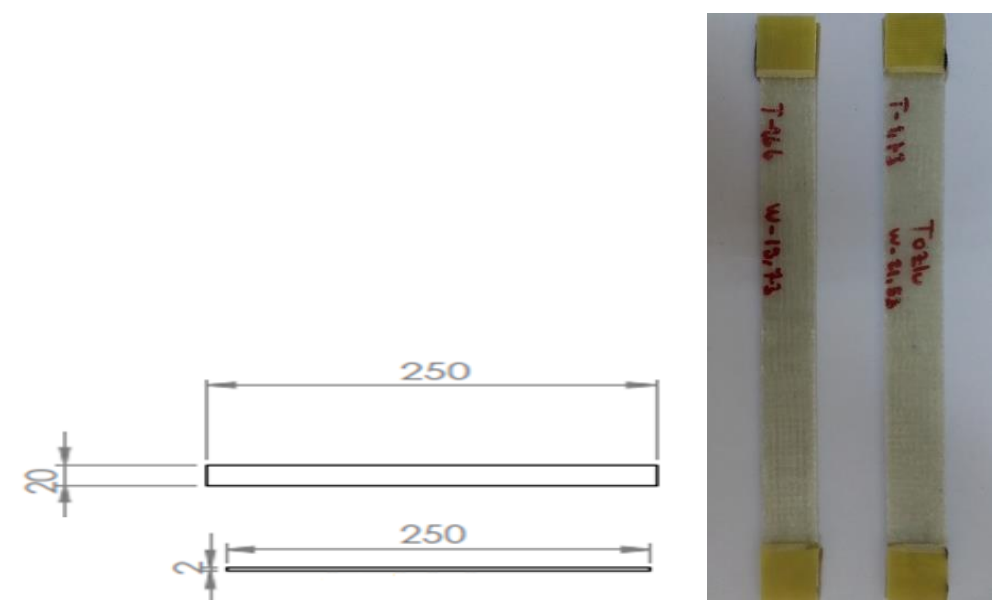

Figure 2. Draw Sample Sizes and Cut Sample Sizes Cut from Composite layers 

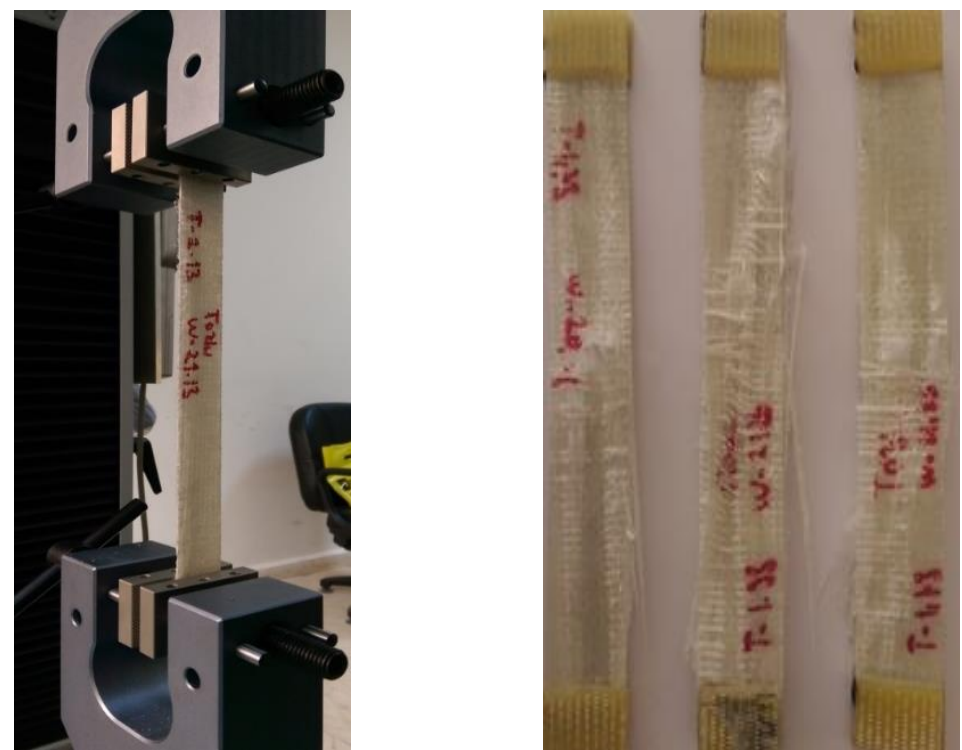

Figure 3. Tensile Test and Sample Damaged Samples

\section{FINDINGS}

In order to improve the damage load and mechanical properties of the composite material, tensile tests were carried out on glass fibre-reinforced composite materials at the particle size applied to the structural adhesive interface. In figure 4, the results of the damage loads obtained from the tensile test are shown in graphical form. The mean values of the damage loads are taken in both graphs. When Figure 4 is examined, it will be seen that the average damage loads of composite materials without particles are $11000 \mathrm{~N}$. Composite materials with glass fibre powders added for reinforcement have an average damage load of around $12000 \mathrm{~N}$. In addition, as shown in Figure 4, each damage load was found to be very close to the average damage load. The addition of composite residual powder to the composite material ensures that the tensile strength, which is among the mechanical properties such as the damage load of the material, is better. The closer the value of each experimental damage load is to the mean damage load, ie the values are close to the average value, and the narrower the indication of the distribution prevalence is. In this case, it means that the experiments are very close to reality and more reliable.

An increase in the amount of elongation and deformation of the composite-added composite materials was also found. Approximately $9 \mathrm{~mm}$ of elongation was observed in the nonparticle samples, but the elongation of the particle-reinforced samples was approximately $11 \mathrm{~mm}$.

\section{RESULTS AND RECOMMENDATIONS}

In this study, tensile tests were performed to compare the experimental damage loads of glass fibre reinforced composite materials produced by hand lay-up method. As a result of the experiments made, the following results were obtained;

1) It was observed that the maximum damage load was $11000 \mathrm{~N}$, but the maximum damage load was $12000 \mathrm{~N}$ when particles were added to the composite material without added particles. Addition of particles to the composite material resulted in a $9.09 \%$ increase in the damage load. For this reason, as a result of our study; it was observed that when composite powders forming during the cutting of composite layers in composite 
production plants were added to the appropriate particle size between structural adhesives, they would increase the tensile strength of composite layers. Therefore, in different composite materials, mechanical strength of composite materials can be expected to increase with different particle reinforcements.
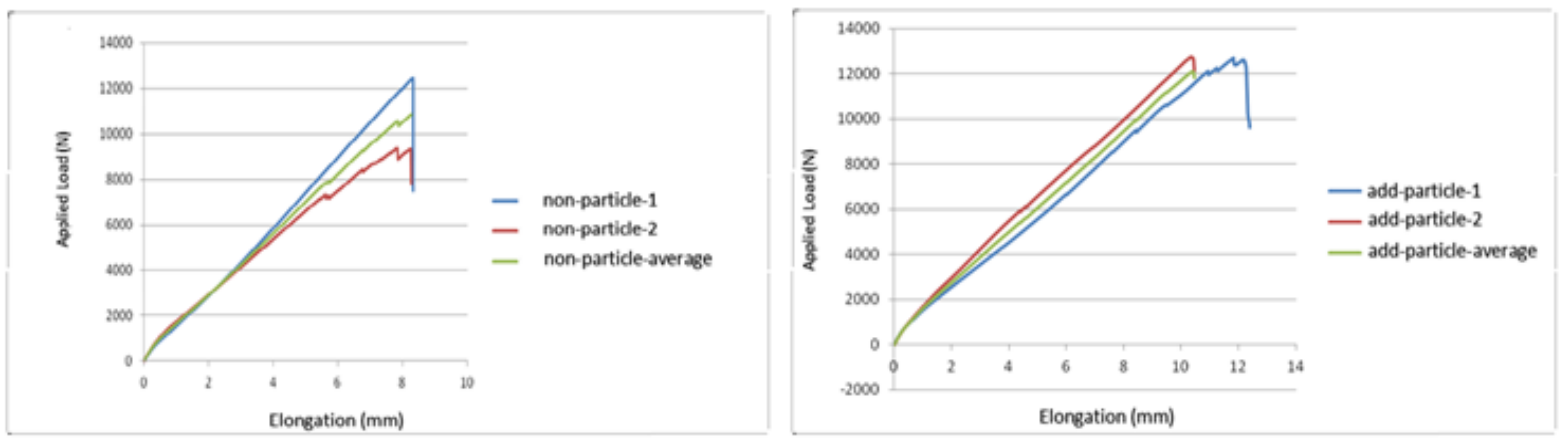

Figure 4. Tensile Test Results of non Particle and add Particle Samples

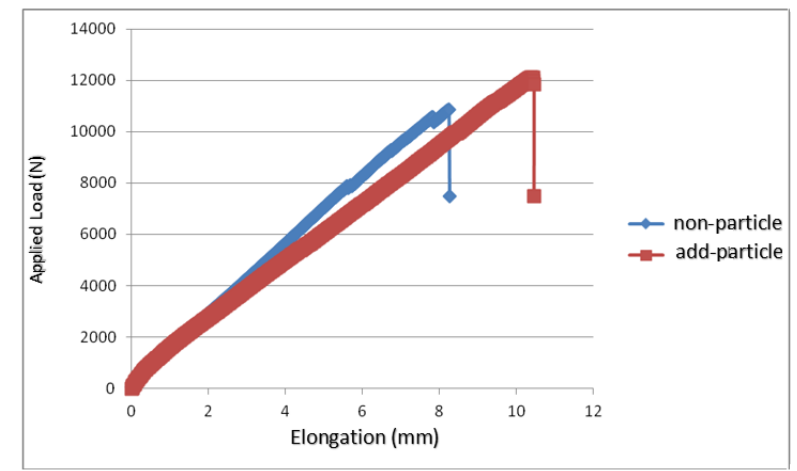

Figure 5. A graphical comparison of the average damage loads of glass fibre non-powdered and glass fibre non-incorporated composite materials

2) Particle addition increases the ability of the composite material to deform. The amount of increase was about $20 \%$ until the time of damage. Therefore, the composite materials can be used in places where more deformation is desired, the ability to deform can be increased by adding particle dust structural adhesives of appropriate size.

\section{References}

[1] Okkalığlu, M., Pekbey, Y., Aktaş, A. Yapıştıııı ile Birleştirilmiş L Tipi Kompozit Köşe Bağlantılarında Çekme Dayanımının Artırılması, Mühendis ve Makina, (2014), 55(649), 50-57.

[2] Türkmen, İ., Köksal, N.S. Cam Elyaf Takviyeli Polyester Matrisli Kompozit Malzemelerde (CTP) Elyaf Tabaka Sayısına Bağlı Mekanik Özelliklerin ve Darbe Dayanımının İncelenmesi," C.B.Ü. Fen Bil. Dergisi, (2013), 17-30.

[3] Uygur, İ. Saruhan, H. Aluminyum Esaslı Metal Matris Kompozit Malzemelerin Mekanik Özellikleri, SAU Fen Bilimleri Enstitüsü Dergisi, 8, (2004), 167-174.

[4] Çiftci, A. Tekstil Boyama ve Baskısında Kullanılan Yardımcı Maddeler, Sümer Yayın, Bursa, 2-5, (1996). 
[5] Genç, M.S. Yapıştırıcı ile Birleştirilmiş Tek Yönlü Tabakalı Kompozit Tek Bindirme Bağlantılarında Hasar Oluşumu ve Gelişimi, Yüksek Lisans Tezi, Erciyes Üniversitesi, Kayseri, (2005).

[6] Beylergil, B. Yapıştırılarak Bağlantı Sağlanan Kompozit Plakaların Bağlantı Performansının Artırılması,” Yüksek Lisans Tezi, Niğde Üniversitesi, Niğde, (2010).

[7] Adin, H. Yapıştırıcı Malzeme İle Birleştirilmiş Ters Z Tipi Bağlantıların Mekanik Etkisi Bindirme, Doktora Tezi, (2007), Firat Üniversitesi, Elaziğg, Turkiye

[8] Ganesh, V.V., Chawla, N. Effect of Particle Orientation Anisotropy on the Tensile Behavior of Metal Matrix Composites: Experiments and Microstructure-based Simulation, Materials Science and Engineering A, (2005), 391, 342-353.

[9] Min, S. Effects of Volume Fraction of SiC Particles on Mechanical Properties of SiC/Al Composites, Transactions of Nonferrous Metals Society of China, 19, (2009), 1400-1404.

[10] Slipenyuk, A., Kuprin, V., Milman, Y, Spowart, J.E., Miracle, D.B. The Effect of Matrix to Reinforcement Particle Size Ratio (PSR) on the Microstructure and Mechanical Properties of a P/M Processed AlCuMn/SiCp MMC, Materials Science and Engineering A, (2004), 381, 165-170.

[11] Liu, Z.Y., Wang, Q.Z., Xiao, B.L., Ma, Z.Y., Liu, Y. Experimental and Modeling Investigation on SiCp Distribution in Powder Metallurgy Processed SiCp/2024 Al Composites, Materials Science and Engineering A, (2010), 527, 5582-5591.

[12] Milan, M.T., Bowen, P. Tensile and Fracture Toughness Properties of SiCp Reinforced Al Alloys: Effects of Particle Size, Particle Volume Fraction, and Matrix Strength, Journal of Materials Engineering and Performance, (2004), 13, 775-783.

[13] Hall, J.N., Jones, J.W., Sachdev, A.K. Particle Size, Volume Fraction and Matrix Strength Effects on Fatigue Behavior and Particle Fracture in 2124 Aluminum-SiCp Composites, Materials Science and Engineering A, (1994), 183, 69-80.

[14] Sun, C., Song, M., Wang, Z. He, Y. Effect of Particle Size on the Microstructures and Mechanical Properties of SiC-reinforced Pure Aluminum Composites, Journal of Materials Engineering and Performance, 20, (2011), 1606-1612.

[15] Varma, K.V., Kamat, S.V., Mahajan, Y.R., Kutumbarao, V. Effect of Reinforcement Size on Low Strain Yielding Behaviour in $\mathrm{Al}-\mathrm{Cu}-\mathrm{Mg} / \mathrm{SiCp}$ Composites,Materials Science and Engineering A, (2001), 318,5764.

[16] O’Donnell, G. and Looney, L. Production of Aluminium Matrix Composite Components Using Conventional PM Technology, Materials Science and Engineering A, (2001), 303, 292-301.

[17] Meguid, S.A., Sun, Y., On the tensile and shear strength of nano-reinforced composite interfaces, Materials and Design, (2004), 25, 289-296

[18] Srivastava, V.K., (2011). Effect of carbon nanotubes on the strength of adhesive lap joints of C/C and C/C$\mathrm{SiC}$ ceramic fibre composites, International Journal of Adhesion and Adhesives, 31, 486-489.

[19] Yildırım, H., P11htıl1, H., Investigation of the mechanic behaviours in hollow composite shafts having different fibre reinforcement and orientation angles, Materialwissenschaft und Werkstofftechic, (2016), 47(7), 646656., Doi:10.1002/mawe.201600509

[20] Khashaba, U.A., Aljinaidi, A.A., Hamed, M.A., Development of CFRE composite scarf adhesive joints with $\mathrm{SiC}$ and $\mathrm{Al}_{2} \mathrm{O}_{3}$ nanoparticle, Composite Structures, (2015), 128, 415-427.

[21] Turan K., Pekbey Y., Progressive Failure Analysis of Reinforced-Adhesively Single-lap Joint, The journal of Adhesion, (2015), 91:12, 962-977. 